\title{
Study on the sensory acceptance and check all that apply of mixed juices in distinct Brazilian regions
}

\author{
Renata Quartieri NASCIMENTO ${ }^{\star *}$ (D), Pedro Paulo Lordelo Guimarães TAVARES ${ }^{1}$, Silvia MEIRELES ${ }^{1}$, \\ Emanuele Araújo dos ANJOS ${ }^{1}$, Roberta Barreto de ANDRADE ${ }^{1}$, Bruna Aparecida Souza MACHADO ${ }^{2}$, \\ Adriana Lucia da Costa SOUZA ${ }^{3}$, Maria Eugênia de Oliveira MAMEDE ${ }^{1}$
}

\begin{abstract}
Fruit juices are on the rise, due to the search new mixes, flavors and nutritional value. This research investigated the acceptance and sensory profile of mixed juices. Sixteen (16) mixed juices with caja, umbu, cocoa and mango flavors were studied, using acceptance and check-all-that-apply (CATA) tests in different cities $(n=226)$. Juices A1 and D1 had the highest scores in Porto Alegre-RS, Brazil (respectively, 7.15 and 6.91). Differently from Salvador-BA, Brazil, where the highest scores were D2 (6.76) and D3 (6.71). Using CATA, it was shown that customers in the Southern Region characterized samples differently from customers in the Northeastern Region, and the correspondence analysis, showed that consumers in Porto Alegre-RS presented different attributes than those in Salvador-BA, with respect to mixed juices and their acceptance. It is suggested the validity of the consumer data in the characterization of the sensory parameters of the mixed juices and that the familiarity with the fruit flavors interfered in the acceptance of the same.
\end{abstract}

Keywords: fruit juices; exotic fruits; check-all-that-apply; consumer acceptance.

Practical Application: The work used an innovative sensory descriptive method called CATA in which the judges select the descriptive terms that characterized the samples in two different regions of the country, one of which does not have the habit of consuming the fruits studied.

\section{Introduction}

The juice market is constantly expanding and studies have indicated that there is a tendency for the consumption of non-alcoholic beverages, motivated by a higher consciousness regarding the use of healthy and functional foods, as well as attractive flavors (Kim \& Kwak, 2015). Silva et al. (2011a) indicated that the beverage market is investing in the commercialization of fruit juices in order to innovate their products and hence the segment of juices has expanded into fruit mixtures (Neves \& Lima, 2010).

Mixed fruit juices with exotic flavors and aromas are being produced using tropical fruits, carbonated or not, with a highly variable fruit juice content (Sousa et al., 2010). These mixtures present the following advantages: the possibility of combining aromas, flavors and nutritional components and sustainability (Lima et al., 2009).

Typical fruits of Brazil's Northeast region, such as caja (Spondias mombin L.), umbu (Spondias tuberosa L.), mango (Mangifera indica L.) and cocoa (Theobroma cacao L.) present interesting and exotic flavors, are sources of vitamins, carotenoids and fibers and could be further studied as viable flavors in the production of mixed juices (Tiburski et al., 2011; Duarte et al., 2010; Bonneau et al., 2016; Efraim et al., 2010).
One way to study these sensory expectations is to apply current methodologies, such as the check-all-that-apply (CATA) test. This method is easily applicable (Ares et al., 2010a), where the sample is presented to the evaluators, along with a predefined list of descriptors terms, from which they are requested to mark all those they believe describes the sample (Ares et al., 2010b). Several recent sensory studies related to CATA method and food products have been conducted in order to verify: the consumer perception of probiotic yogurt using different consumer profiling techniques (Cruz et al., 2013); the performance of a CATA questionnaire as a tool to provide sensory profile of requeijão cremoso (Torres et al., 2017); the temperature-dependent sensory-attribute variations of cooked rice and their association with frequency of consumption (Pramudya \& Seo, 2018); the application of CATA as a predictor tool of food choices of children in comparison to hedonic liking (Verwaeren et al., 2019); the use of rating scales versus CATA to quantify Cannabis aroma (Gilbert \& DiVerdi, 2019); mouthfeel and texture properties of red wines (Kemp et al., 2019) and consumer perception in relation to Syrah wine produced São Francisco Valley, Brazil, at different fermentation stages (Alencar et al., 2019) using the CATA method.

${ }^{2}$ Faculdade de Tecnologia, Serviço Nacional de Aprendizagem Industrial - SENAI CIMATEC, Salvador, BA, Brasil

${ }^{3}$ Departamento de Nutrição, Universidade Federal de Sergipe - UFS, Lagarto, SE, Brasil

${ }^{*}$ Corresponding author: rqnutri@gmail.com 
In a study with mixed flavor juices in two different Brazilian regions, Mamede et al. (2015) stated that in order for a beverage to reach the market, the target audience must be well-accepted, which will depend on cultural diversification, as they affect their acceptance and cause variations in taste patterns. Bonany et al. (2013) reported that studies with different apple varieties in several European countries indicated that regional conditions influenced their acceptance. Considering that Brazil has a highly diversified culture with variations in taste preferences, this study proposed the use of a sensory evaluation for acceptance and CATA to evaluate mixed juices based on the following tropical fruit pulps: umbu (Spondias tuberosa L.), cocoa (Theobroma cacau L.), cajá (Spondias mombim L.) and mango (Mangifera indica L.) in two Brazilian regions.

\section{Materials and methods}

\subsection{Samples and preparation}

Samples, of pasteurized and frozen caja, umbu, mango (Doce Mel brand) and cocoa (Santa Rosa brand) pulps, all purchased from local distributors, paying attention to the expiration date and registration. These fruit pulps were chosen considering their importance for the northeast region and also their flavor characteristics. The pulps were weighed while still frozen and subsequently homogenized with sugar and water.

The study comprised sixteen (16) samples, divided into four (4) formulations each containing three (3) different pulp flavors, designated with the letters A, B, C and D, with four (4) concentrations of each, as shown in Table 1. Preliminary studies were carried out with flavor mixtures in order to choose the proportions, considering the acidity and sweetness of each fruit. The pulp ratios were in agreement with the Brazilian legislation, which establishes a minimum of $50 \%$ fruit pulp for mixed tropical juices (Brasil, 2003), plus 10\% crystal sugar (Caeté brand) and $40 \%$ mineral water.

\subsection{Acceptance test}

The acceptance test was applied in the cities of Porto Alegre-RS (Southern region of Brazil) and Salvador-BA (Northeastern region of Brazil). Fruit juice consumers were recruited at the Federal University of Rio Grande do Sul and at the Federal University of Bahia, based on their interest and willingness to participate in the study. Two hundred and twenty-six consumers (one hundred and thirteen in each city) took part in the test. The number of participants was chosen according to the suggestion of Hough et al. (2006), to minimize the effects of the Type I error. The participants were aged between 18 and 60 and all signed a consent form and filled in the recruitment sheet.
The two groups evaluated were previously informed about the products and procedures (scale and evaluation tests), as described in the project registered in the National System of Ethics in Research (CAE 51007515.7.0000.5531/ UFBA).

The evaluations were carried out in individual booths under artificial light, with a temperature between 22 and $24^{\circ} \mathrm{C}$ and air circulation, the samples being evaluated in a monadic sequential manner. The tests were carried out in a single session, with the presentation of the sixteen (16) samples following a complete outline of sets, balanced with respect to the sample presentation order (MacFie et al., 1989). To avoid fatigue, the evaluators were allowed a thirty-minute break after every eight (8) samples. The samples $(45 \mathrm{~mL})$ were served in plastic cups encoded with random three-digit numbers. A structured hedonic nine-point scale, ranging from 1 - "strongly disliked" to 9 - "strongly liked" was used to assess overall acceptance (Meilgaard \& Civille, 2007). Consumers were also asked to describe what they liked and disliked in the samples on a general basis. Salty biscuits were provided to neutralize the taste and mineral water to rinse the mouth, between samples.

\subsection{Check-All-That-Apply (CATA) test}

The CATA test was applied in the cities of Porto Alegre-RS and Salvador-BA in the same acceptance test session.

The sensory team was selected by applying a triangular test carried out with twenty four (24) participants using samples $\mathrm{A} 1$ and $\mathrm{A} 4 ; \mathrm{B} 1$ and $\mathrm{B} 4 ; \mathrm{C} 1$ and $\mathrm{C} 4 ; \mathrm{D} 1$ and $\mathrm{D} 4$, and analyzed by the specific test table (Minimum Number of Triangular Test Responses) at the $5 \%$ level of significance (Meilgaard \& Civille, 2007). Only the evaluators who correctly discriminated the pairs of sample combinations presented were selected to part in the evaluation team that generated the descriptors for CATA. The final team was composed of sixteen (16) evaluators from the city of Salvador-BA.

After the formation of the team, a survey was carried out using the Kelly Network Method (Moskowitz, 1983) to describe the descriptive terms of the juices, for which two meetings were called to describe the attributes. The terms were ratified in the city of Porto Alegre-RS by a team of 16 evaluators (who reported consuming fruit juice frequently), with the inclusion of two new terms not recognized by the Salvador-BA team.

The final CATA list consisted of a total of nineteen (19) terms; For Appearance: yellow color (YC), greenish color (GC), brightness (B), foam (F), turbidity (T) and visual viscosity (VV); For Aroma: characteristic aroma of caja (CAC), characteristic aroma of cocoa (CACC), sweet aroma (SA), characteristic aroma

Table 1. Preparation of mixed juice formulations in percentage of each fruit (\%).

\begin{tabular}{|c|c|c|c|c|c|c|c|c|c|c|c|c|c|c|c|c|}
\hline \multirow{2}{*}{ Flavors } & \multicolumn{16}{|c|}{ SAMPLES } \\
\hline & $\mathrm{A} 1$ & $\mathrm{~A} 2$ & A3 & A4 & B1 & B2 & B3 & B4 & $\mathrm{C} 1$ & $\mathrm{C} 2$ & $\mathrm{C} 3$ & $\mathrm{C} 4$ & D1 & D2 & D3 & D4 \\
\hline Caja (\%) & 50 & 40 & 35 & 30 & 50 & 40 & 35 & 30 & - & - & - & - & 25 & 30 & 45 & 50 \\
\hline Umbu (\%) & 25 & 30 & 20 & 20 & 25 & 30 & 20 & 20 & 25 & 30 & 45 & 50 & - & - & - & - \\
\hline Cocoa $(\%)$ & 25 & 30 & 45 & 50 & - & - & - & - & 50 & 40 & 35 & 30 & 50 & 40 & 35 & 30 \\
\hline Mango (\%) & - & - & - & - & 25 & 30 & 45 & 50 & 25 & 30 & 20 & 20 & 25 & 30 & 20 & 20 \\
\hline
\end{tabular}

Juices: Group A (caja, umbu and cocoa); Group B (caja, umbu and mango); Group C (cocoa, mango and umbu); Group D (cocoa, mango and caja). 
of mango (CAM) and characteristic aroma of umbu (CAU); For Flavor and Oral Perceptions: acid taste (AT), acid flavor of caja (AFC), sweet taste (ST), mango flavor (MF), sweet flavor of cocoa (SFCC), fruit flavor (FF), acid flavor of cocoa (AFCC) and viscosity $(\mathrm{V})$.

After defining the descriptors, the analysis started with the 226 evaluators, being carried out first in Porto Alegre-RS and then in Salvador-BA. The evaluators were asked to mark all the terms they considered to be characteristic of the product when tasting the sample. It should be noted that the records were produced in different presentation orders to minimize the effect of attribute distribution by the evaluators (Ares et al., 2013).

\subsection{Physical and chemical analyses}

All the physicochemical analyses were done in order to compare with the acceptance and CATA results by the Multiple Factorial Analysis. $\mathrm{pH}$ and titratable acidity (TA) were determined by AOAC (Association of Official Analytical Chemist, 1995) methodology. Total soluble solids (TSS) were analyzed using a portable digital refractometer (Kruss Model DR 201-95). The soluble solids (TSS)/ total acidity (TTA) ratio was also calculated.

The viscosity was measured using a viscometer (Brookfield Model DV-I Prime) with spindle S63, $60 \mathrm{rpm}$ of rotation and torque $>10$. For the color analysis, a Konica Minolta CR 5 benchtop colorimeter (Tokyo, Japan) was used in transmittance mode, calibrated for white at 100\%, using illuminant D65 and the CIELAB reading system, obtaining values for brightness $\left(L^{\star}\right)$, Chroma $\left(C^{\star}\right)$ and hue $\left(h^{*}\right)$.

\subsection{Statistical analysis}

A completely randomized experimental design was used with a factorial arrangement, studying the pulp ratio variables in each composition. The acceptance and physicochemical data obtained in each city were submitted to ANOVA followed by Tukey's means test $(\mathrm{p}<0.05)$. The t-test was applied to compare the means between the two cities, and Pearson's correlation test to determine the degree of correlation between the acceptance test in each city and the physicochemical parameters, using the SAS University Edition program version 1.7.0_76.

The results obtained for CATA were evaluated according to the frequency with which each attribute was mentioned for each sample, and the statistical differences $(\mathrm{p}<0.05)$ were evaluated by Cochran's Q test (Meyners et al., 2013). Correspondence analyses were also carried out for each city (34 rows, 4 columns), and the RV coefficient calculated to compare the two matrices. For this calculation, the greenish attribute selected in Porto Alegre-RS was removed, since this attribute was not selected in Salvador-BA. The multiple factorial analysis was applied to report the data sets (acceptance, CATA and physicochemical) for each city (Ares et al., 2013) (28 rows, 15 columns). The statistical analyses were carried out using XLSTAT (Addinsoft) 17.04.

\section{Results and discussion}

\subsection{Consumer characterization}

The comparison between the consumers in the cities of Salvador-BA and Porto Alegre-RS showed that the predominant age group was between 21 and 30 years in both cases. The fruit juice consumption frequency was $55.8 \%$ and $34.5 \%$ for the daily consumption option for the northeastern and southern regions, respectively. When questioned about liking fruit juice, the incidence was higher in Porto Alegre-RS (93.8\%) than in Salvador-BA (87.6\%).

\subsection{Juice acceptance}

The results obtained for juice acceptance in the Southern and Northeastern regions can be seen in Table 2. In the Southern region, juices $\mathrm{A} 1$ and $\mathrm{D} 1$ presented the highest scores of 7.15 and 6.91, respectively. There was statistical difference $(\mathrm{p}<0.05)$ between sample A1 and the samples C1, C3 and C4. The sample D1 differed statistically only from the sample C4. In Salvador-BA, the juices presenting the highest scores were D2 and D3 with scores of 6.76 and 6.71, respectively, and differed only from the sample $\mathrm{C} 4$.

The $\mathrm{C}$ group samples tended to present the worst results. Juice $\mathrm{C} 4$ showed the statistically smallest acceptance $(\mathrm{p}<0.05)$ with a score of 6.14 , and samples $\mathrm{C} 1$ with a score of 6.30 and $\mathrm{C} 3$ with a score 6.20 showed statistically lower acceptance than juice A1, which was more accepted. In Salvador-BA, the same sample, C4, had a score of 5.54, showing statistically lower acceptance than

Table 2. Acceptance scores for the mixed juices.

\begin{tabular}{ccc}
\hline & \multicolumn{2}{c}{ Acceptance } \\
\cline { 2 - 3 } Juices & $\begin{array}{c}\text { Porto Alegre }- \text { RS } \\
(\mathrm{n}=113)\end{array}$ & $\begin{array}{c}\text { Salvador }- \text { BA } \\
(\mathrm{n}=113)\end{array}$ \\
\hline A1 & $7.15^{\mathrm{a}}(1.49)$ & $6.38^{\mathrm{a}}(1.59)$ \\
A2 & $6.84^{\mathrm{abc}}(1.55)$ & $6.47^{\mathrm{a}}(1.44)$ \\
A3 & $6.90^{\mathrm{abc}}(1.55)$ & $6.31^{\mathrm{a}}(1, .0)$ \\
A4 & $6.83^{\mathrm{abc}}(1.45)$ & $6.35^{\mathrm{a}}(1.61)$ \\
B1 & $6.61^{\mathrm{abc}}(1.72)$ & $6.32^{\mathrm{a}}(1.61)$ \\
B2 & $6.45^{\mathrm{abc}}(1.74)$ & $6.29^{\mathrm{ab}}(1.60)$ \\
B3 & $6.87^{\mathrm{abc}}(1.71)$ & $6.37^{\mathrm{a}}(1.61)$ \\
B4 & $6.56^{\mathrm{abc}}(1.71)$ & $6.69^{\mathrm{a}}(1.63)$ \\
C1 & $6.30^{\mathrm{bc}}(1.60)$ & $6.18^{\mathrm{ab}}(1.83)$ \\
C2 & $6.51^{\mathrm{abc}}(1.74)$ & $6.23^{\mathrm{ab}}(1.71)$ \\
C3 & $6.20^{\mathrm{bc}}(1.66)$ & $6.02^{\mathrm{ab}}(1.92)$ \\
C4 & $6.14^{\mathrm{c}}(1.80)$ & $5.54^{\mathrm{b}}(2.03)$ \\
D1 & $6.91^{\mathrm{ab}}(1.76)$ & $6.67^{\mathrm{a}}(1.83)$ \\
D2 & $6.83^{\mathrm{abc}}(1.77)$ & $6.76^{\mathrm{a}}(1.49)$ \\
D3 & $6.89^{\mathrm{abc}}(1.74)$ & $6.71^{\mathrm{a}}(1.53)$ \\
D4 & $6.70^{\mathrm{abc}}(1.81)$ & $6.45^{\mathrm{a}}(1.80)$ \\
P (Anova) & 0.001 & 0.001 \\
\hline
\end{tabular}

Values are means with standard deviation between brackets. Means followed the same letters in the same column do not differ statistically ( $p>0.05$ ) according to the Tukey test, taking into account the ANOVA assumptions. "n" value corresponds to the number of consumers that participated in the sensory analysis and "p-value" represents the statistical significance, where a $\mathrm{p}<0.05$ indicates a statistically significant difference between samples. Juices: Group A (caja, umbu and cocoa); Group B (caja, umbu and mango); Group C (cocoa, mango and umbu); Group D (cocoa, mango and caja). 
several other samples, but was not significantly different $(\mathrm{p}<0.05)$ from the other Group C samples.

In general, all the juices from both regions received good scores and no beverage in either city scored below 5.0, showing a good acceptance potential for the mixed juices. In addition, consumers in Porto Alegre-RS proved to be more demanding, since they presented three distinct groups of statistical acceptance, whereas the consumers in Salvador-BA only separated the samples into two distinct statistical groups (Table 2). This can be explained by the greater habit of consuming tropical juices such as caja, umbu and cocoa in the Brazilian Northeast, since they are typical fruits of this region. In a study developed by Silva et al. (2011b), using mixed juices with the addition of prebiotics, average scores between 5.8 and 7.0 were obtained, supporting those verified in the present study.

In the $t$ test, there was a significant difference in the acceptance score between the two cities for the juices A1, A3, A4, B3 and C4, as shown in Table 3. It can be seen that the juices that obtained the highest scores in Salvador-BAhia showed no differences in relation to Porto Alegre-RS, which can be justified by the fact that in both regions the same products obtained the same acceptance, and the differences between the locations did not affect the choices of the evaluators. In a study of mixed fruit flavored beverages, Mamede et al. (2015) showed that consumer behavior was little influenced by regional differences and familiarity with a product.

In the opening question, the attributes the evaluators most liked in the juices were appearance, aroma, flavor/taste, viscosity and astringency. Flavor/taste was the one most liked in both cities, with percentage of $46 \%$ in Salvador-BA and $48.7 \%$ in Porto Alegre-RS. Jaekel et al. (2010) stated that the sensory quality of the products is one of the most important factors, since this is decisive in the consumer's choice of beverage, especially when associated with the flavor attribute, which overlaps with other sensory properties.

Pearson's correlation was used to evaluate the acceptance data obtained in the two cities and the physicochemical parameters. In Porto Alegre-RS there was no correlation for the parameter of $\mathrm{pH}$, and as a counterpart, in Salvador-BA there was also no correlation for the parameter of total acidity. The correlation showed that the color parameters showed greater correlation with acceptance, and hence as from this statistical analysis one can consider that color is an important parameter for juice acceptance. Teixeira (2009) affirmed that the first contact of a consumer with a product is generally the visual presentation, where color and appearance stand out. All products have an expected color and appearance, which are associated with the personal reactions of acceptance, indifference or rejection.

A strong, negative correlation was observed in the southern region between acceptance and the acidity of juice D2, suggesting that the less acid the product the more accepted. In the northeastern region the parameter of $\mathrm{pH}$ also showed a strong negative and positive correlation with juices A2 and A4, respectively, and could therefore have contributed to their acceptance.

\subsection{Check-All-That-Apply (CATA)}

Tables 4 and 5 indicate the frequency with which the evaluators marked each attribute of each sample. There was no statistical difference between the samples $(p>0.05)$ for the following attributes in Porto Alegre-RS: visual viscosity, characteristic aroma of caja, characteristic aroma of cocoa, sweet aroma, fruit flavor, acidic flavor of cocoa or viscosity. For Salvador-BA, the attributes with no statistical difference were: greenish color, visual viscosity, sweet flavor of cocoa and

Table 3. Comparative t-test for acceptance of the mixed juice averages.

\begin{tabular}{|c|c|c|c|c|c|c|}
\hline \multirow[b]{2}{*}{ Juices } & \multicolumn{2}{|c|}{ Cities } & \multirow[b]{2}{*}{$\mathrm{t}$-Value } & \multirow[b]{2}{*}{$\mathrm{p}$-Value } & \multicolumn{2}{|c|}{$\mathrm{t}$-test } \\
\hline & $\begin{array}{l}\text { Porto Alegre-RS } \\
\quad(\mathrm{n}=113)\end{array}$ & $\begin{array}{c}\text { Salvador-BA } \\
\quad(\mathrm{n}=113)\end{array}$ & & & Porto Alegre-RS & Salvador-BA \\
\hline A1 & 7.15 & 6.38 & 3.62 & 0.000 & 1.49 & 1.59 \\
\hline $\mathrm{A} 2$ & 6.84 & 6.47 & 1.73 & 0.086 & 1.55 & 1.44 \\
\hline A3 & 6.90 & 6.31 & 2.75 & 0.007 & 1.53 & 1.46 \\
\hline $\mathrm{A} 4$ & 6.83 & 6.35 & 2.28 & 0.025 & 1.45 & 1.62 \\
\hline B1 & 6.61 & 6.32 & 1.24 & 0.216 & 1.72 & 1.61 \\
\hline B2 & 6.45 & 6.29 & 0.67 & 0.503 & 1.73 & 1.56 \\
\hline B3 & 6.87 & 6.37 & 2.47 & 0.015 & 1.66 & 1.59 \\
\hline B4 & 6.56 & 6.69 & -0.59 & 0.556 & 1.71 & 1.63 \\
\hline $\mathrm{C} 1$ & 6.30 & 6.18 & 0.12 & 0.904 & 1.53 & 1.83 \\
\hline $\mathrm{C} 2$ & 6.51 & 6.23 & 1.30 & 0.197 & 1.69 & 1.68 \\
\hline $\mathrm{C} 3$ & 6.20 & 6.02 & 0.69 & 0.492 & 1.61 & 1.92 \\
\hline $\mathrm{C} 4$ & 6.14 & 5.54 & 2.60 & 0.011 & 1.74 & 2.03 \\
\hline D1 & 6.91 & 6.67 & 0.91 & 0.366 & 1.67 & 1.83 \\
\hline D2 & 6.83 & 6.76 & 0.46 & 0.642 & 1.72 & 1.48 \\
\hline D3 & 6.89 & 6.71 & 0.99 & 0.323 & 1.75 & 1.50 \\
\hline D4 & 6.70 & 6.45 & 1.18 & 0.242 & 1.81 & 1.80 \\
\hline
\end{tabular}

Values for the t-test for the comparison of means, where $\mathrm{p}<0.05$ shows a statistical difference between the cities studied. "n" value corresponds to the number of consumers that participated in the sensory analysis and "p-value" represents the statistical significance, where a $p<0.05$ indicates a statistically significant difference between samples. Juices: Group A (caja, umbu and cocoa); Group B (caja, umbu and mango); Group C (cocoa, mango and umbu); Group D (cocoa, mango and caja). 
Table 4. Number of times the attribute was scored by the evaluators for each mixed juice sample in the city of Porto Alegre-RS.

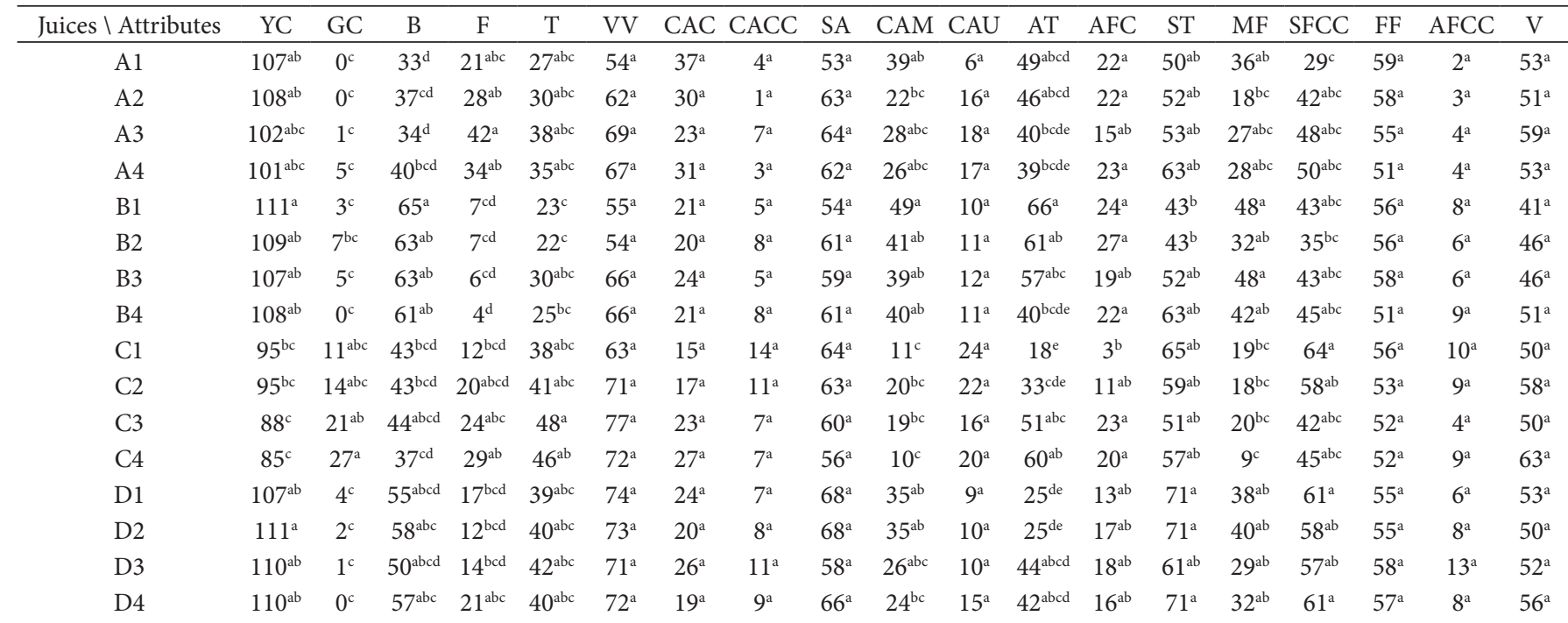

P-value

(Cochran's Q)

$\begin{array}{lllllllllllllllllll}0.000 & 0.000 & 0.000 & 0.000 & 0.000 & 0.000 & 0.004 & 0.018 & 0.292 & 0.000 & 0.000 & 0.000 & 0.000 & 0.000 & 0.000 & 0.000 & 0.985 & 0.082 & 0.043\end{array}$

Attributes: YC (Yellow Color); GC (Greenish Color); B (Brightness); F (Foam); T (Turbidity); VV (Visual Viscosity); CAC (Characteristic Aroma of Caja); CACC (Characteristic Aroma of Cocoa); SA (Sweet Aroma); CAM (Characteristic Aroma of Mango); CAU (Characteristic Aroma of Umbu); AT (Acidic Taste); AFC (Acidic Flavor of Caja); ST (Sweet Taste); MF (Mango Flavor); SFCC (Sweet Flavor of Cocoa); FF (Fruit Flavor); AFCC (Acidic Flavor of Cocoa); and V (Viscosity). The "p-value" represents the Statistical Significance, where a $\mathrm{p}<0.05$ correponds to a statistically significant difference between samples. Juices: Group A (caja, umbu and cocoa); Group B (caja, umbu and mango); Group C (cocoa, mango and umbu); Group D (cocoa, mango and caja). The values are the frequency with which each attribute was marked for each sample. Values followed by equal letters in the same column did not differ statistically $(\mathrm{p}>0.05)$ according to the Cochran test $(\mathrm{n}=113)$.

Table 5. Number of times the attribute was scored by the evaluators for each mixed juice sample in the city of Salvador-BA.

\begin{tabular}{|c|c|c|c|c|c|c|c|c|c|c|c|c|c|c|c|c|c|c|c|}
\hline Juices $\backslash$ Attributes & $\mathrm{YC}$ & GC & $\mathrm{B}$ & $\mathrm{F}$ & $\mathrm{T}$ & VV & CAC & CACC & SA & CAM & $\mathrm{CAU}$ & $\mathrm{AT}$ & $\mathrm{AFC}$ & ST & MF & SFCC & $\mathrm{FF}$ & AFCC & $\mathrm{V}$ \\
\hline $\mathrm{A} 1$ & $110^{\mathrm{a}}$ & $0^{\mathrm{a}}$ & $45^{\mathrm{abc}}$ & $9^{\text {cd }}$ & $24^{\mathrm{b}}$ & $53^{\mathrm{a}}$ & $84^{\mathrm{a}}$ & $7^{\mathrm{bcd}}$ & $24^{\mathrm{ab}}$ & $16^{\text {ef }}$ & $8^{\mathrm{dc}}$ & $50^{\mathrm{abc}}$ & $67^{\mathrm{ab}}$ & $20^{\mathrm{d}}$ & $15^{\text {cdef }}$ & $24^{\mathrm{a}}$ & $30^{\mathrm{a}}$ & $6^{\mathrm{bc}}$ & $31^{\mathrm{a}}$ \\
\hline $\mathrm{A} 2$ & $102^{\mathrm{a}}$ & $0^{\mathrm{a}}$ & $37^{\mathrm{bc}}$ & $11^{\mathrm{bcd}}$ & $33^{\mathrm{ab}}$ & $65^{\mathrm{a}}$ & $82^{\mathrm{a}}$ & $8^{\mathrm{abcd}}$ & $25^{\mathrm{ab}}$ & $15^{\mathrm{ef}}$ & $9^{\mathrm{d} c}$ & $39^{\mathrm{bcd}}$ & $69^{\mathrm{a}}$ & $28^{\mathrm{bcd}}$ & $12^{\text {def }}$ & $22^{\mathrm{a}}$ & $27^{\mathrm{a}}$ & $7^{\mathrm{bc}}$ & $31^{\mathrm{a}}$ \\
\hline A3 & $106^{\mathrm{a}}$ & $0^{\mathrm{a}}$ & $35^{\mathrm{bc}}$ & $14^{\mathrm{bcd}}$ & $36^{\mathrm{ab}}$ & $52^{\mathrm{a}}$ & $78^{\mathrm{ab}}$ & $6^{\mathrm{bcd}}$ & $30^{\mathrm{ab}}$ & $14^{\mathrm{ef}}$ & $15^{\mathrm{bcd}}$ & $37^{\mathrm{bcd}}$ & $65^{\mathrm{ab}}$ & $42^{\mathrm{abcd}}$ & $14^{\text {def }}$ & $28^{\mathrm{a}}$ & $32^{\mathrm{a}}$ & $4^{c}$ & $32^{\mathrm{a}}$ \\
\hline B1 & $108^{\mathrm{a}}$ & $0^{\mathrm{a}}$ & $55^{\mathrm{ab}}$ & $5^{\mathrm{cd}}$ & $25^{\mathrm{b}}$ & $61^{\mathrm{a}}$ & $60^{\mathrm{abc}}$ & $2^{\mathrm{cd}}$ & $28^{\mathrm{ab}}$ & $45^{\mathrm{bcd}}$ & $8^{\mathrm{cd}}$ & $59^{\mathrm{ab}}$ & $53^{\mathrm{abcd}}$ & $23^{\mathrm{cd}}$ & $38^{\mathrm{abc}}$ & $19^{\mathrm{a}}$ & $32^{\mathrm{a}}$ & $2^{c}$ & $38^{\mathrm{a}}$ \\
\hline B2 & $104^{\mathrm{a}}$ & $0^{\mathrm{a}}$ & $59^{\mathrm{a}}$ & $2^{\mathrm{d}}$ & $26^{\mathrm{b}}$ & $71^{\mathrm{a}}$ & $46^{\text {cde }}$ & $4^{\mathrm{bcd}}$ & $33^{\mathrm{ab}}$ & $47^{\mathrm{bc}}$ & $9^{c d}$ & $45^{\mathrm{abcd}}$ & $51^{\mathrm{abcde}}$ & $30^{\mathrm{bcd}}$ & $41^{\mathrm{ab}}$ & $24^{\mathrm{a}}$ & $29^{a}$ & $7^{b c}$ & $34^{\mathrm{a}}$ \\
\hline $\mathrm{C} 1$ & $69^{c}$ & $0^{\mathrm{a}}$ & $33^{\mathrm{bc}}$ & $16^{\mathrm{bcd}}$ & $48^{\mathrm{a}}$ & $58^{\mathrm{a}}$ & $19^{\mathrm{f}}$ & $26^{\mathrm{a}}$ & $34^{\mathrm{ab}}$ & $26^{\text {cdef }}$ & $31^{\mathrm{b}}$ & $24^{\mathrm{de}}$ & $19^{\mathrm{g}}$ & $53^{\mathrm{ab}}$ & $23^{\text {bcdef }}$ & $36^{\mathrm{a}}$ & $36^{\mathrm{a}}$ & $31^{\mathrm{a}}$ & $35^{\mathrm{a}}$ \\
\hline $\mathrm{C} 2$ & $81^{\mathrm{bc}}$ & $0^{\mathrm{a}}$ & $44^{\mathrm{abc}}$ & $16^{\mathrm{bcd}}$ & $37^{\mathrm{ab}}$ & $61^{\mathrm{a}}$ & $23^{\mathrm{ef}}$ & $13^{\mathrm{abcd}}$ & $42^{\mathrm{a}}$ & $36^{\text {cde }}$ & $24^{\mathrm{bc}}$ & $34^{\text {bcde }}$ & $27^{\mathrm{efg}}$ & $44^{\mathrm{abc}}$ & $35^{\mathrm{bcd}}$ & $35^{\mathrm{a}}$ & $34^{\mathrm{a}}$ & $14^{\mathrm{abc}}$ & $46^{\mathrm{a}}$ \\
\hline $\mathrm{C} 3$ & $42^{\mathrm{d}}$ & $0^{\mathrm{a}}$ & $34^{\mathrm{bc}}$ & $36^{\mathrm{a}}$ & $45^{\mathrm{ab}}$ & $60^{\mathrm{a}}$ & $21^{\mathrm{f}}$ & $16^{\mathrm{abc}}$ & $26^{\mathrm{ab}}$ & $10^{\mathrm{f}}$ & $66^{\mathrm{d}}$ & $56^{\mathrm{ab}}$ & $21^{\mathrm{fg}}$ & $36^{\mathrm{bcd}}$ & $10^{\mathrm{ef}}$ & $30^{\mathrm{a}}$ & $39^{a}$ & $20^{\mathrm{ab}}$ & $42^{\mathrm{a}}$ \\
\hline $\mathrm{C} 4$ & $32^{\mathrm{d}}$ & $0^{\mathrm{a}}$ & $30^{c}$ & $31^{\mathrm{ab}}$ & $41^{\mathrm{ab}}$ & $61^{a}$ & $22^{\mathrm{f}}$ & $12^{\mathrm{abcd}}$ & $19^{\mathrm{b}}$ & $9^{f}$ & $68^{\mathrm{a}}$ & $68^{\mathrm{a}}$ & $18^{\mathrm{g}}$ & $24^{\mathrm{cd}}$ & $7^{f}$ & $29^{a}$ & $39^{\mathrm{a}}$ & $13^{\mathrm{abc}}$ & $40^{\mathrm{a}}$ \\
\hline D1 & $106^{a}$ & $0^{\mathrm{a}}$ & $53^{\mathrm{ab}}$ & $10^{\mathrm{cd}}$ & $28^{\mathrm{b}}$ & $61^{\mathrm{a}}$ & $44^{\text {cde }}$ & $5^{\text {bcd }}$ & $37^{\mathrm{ab}}$ & $47^{\mathrm{abc}}$ & $1^{\mathrm{d}}$ & $14^{\mathrm{e}}$ & $37^{\text {cdefg }}$ & $62^{\mathrm{a}}$ & $42^{\mathrm{ab}}$ & $40^{\mathrm{a}}$ & $33^{\mathrm{a}}$ & $4^{\mathrm{bc}}$ & $32^{\mathrm{a}}$ \\
\hline
\end{tabular}

Attributes: YC (Yellow Color); GC (Greenish Color); B (Brightness); F (Foam); T (Turbidity); VV (Visual Viscosity); CAC (Characteristic Aroma of Caja); CACC (Characteristic Aroma of Cocoa); SA (Sweet Aroma); CAM (Characteristic Aroma of Mango); CAU (Characteristic Aroma of Umbu); AT (Acidic Taste); AFC (Acidic Flavor of Caja); ST (Sweet Taste); MF (Mango Flavor); SFCC (Sweet Flavor of Cocoa); FF (Fruit Flavor); AFCC (Acidic Flavor of Cocoa); and V (Viscosity); The "p-value" represents the Statistical Significance, where a p $<0.05$ correponds to a statistically significant difference between samples. Juices: Group A (caja, umbu and cocoa); Group B (caja, umbu and mango); Group C (cocoa, mango and umbu); Group D (cocoa, mango and caja). The values are the frequency with which each attribute was marked for each sample. Values followed by equal letters in the same column did not differ statistically $(\mathrm{p}>0.05)$ by the Cochran test $(\mathrm{n}=113)$.

viscosity. In a study with yogurts, whey drinks and fermented milks using the same sensory methodology, Farah et al. (2017) suggested that attributes that did not show any significant difference could not be considered responsible for accepting or rejecting a particular sample.
Nevertheless it can also be seen that other terms differed between the samples $(\mathrm{p}<0.05)$, such as, for example, the attributes of yellow color, greenish color, brightness, foam, turbidity, characteristic aroma of mango, acidic taste, acidic flavor of caja, sweet taste, mango flavor and sweet cocoa flavor in the Southern 
region. Of these attributes, those of yellow color and sweet taste for juices $\mathrm{A} 1$ and $\mathrm{D} 1$ received significant emphasis. The juice $\mathrm{C} 4$ showed a significant difference $(\mathrm{p}<0.05)$ for the attribute greenish color when compared with the samples of groups A, B and D.

In the Northeastern region the attributes with the greatest frequency and which differed significantly $(\mathrm{p}<0.05)$ were: yellow color, brightness, foam, turbidity, characteristic aroma of caja, characteristic aroma of cocoa, sweet aroma, characteristic aroma of mango, characteristic aroma of umbu, acidic taste, acidic flavor of caja, sweet taste, mango flavor, and acidic flavor of cocoa. Of these attributes, yellow color, brightness and characteristic aroma of caja for juices D2 and D3 received the most significant emphasis. The consumers in Salvador-BA appear to have significantly differentiated $(\mathrm{p}<0.05)$ a greater number of attributes for the juices, which can be explained by the greater habit of this population to consume tropical juices of the fruits used in this study.

Using the CATA results, correspondence analyses were carried out for each region. Figure 1 refers to the analysis carried out in Porto Alegre-RS, indicating that the dimensions accounted for $75.5 \%$ of the total variation in the data $(47.68 \%$ for dimension I and $27.80 \%$ for dimension II). It can be seen that samples A1, B1 and B2 were more associated with the following attributes: characteristic aroma of caja, acidic flavor of caja, characteristic aroma of mango, fruit flavor, yellow color and acidic taste. The samples A2, A3, A4, C3 and C4 were more associated with the attributes of foam and viscosity. It can also be seen that the attributes of sweet cocoa flavor, characteristic aroma of cocoa and acidic flavor of cocoa characterized the samples D4, D3 and C2, as also the attributes of sweet taste and sweet aroma, due to their proximity.
On the other hand, Figure 2 (Salvador-BA) showed that dimensions I and II accounted for $83.58 \%$ of the total variation in the data (56.54\% for dimension I and $27.05 \%$ for dimension II). The group C juices (C1, C2, C3 and C4) can be seen to be associated with the attributes of characteristic aroma of umbu, acidic flavor of cocoa and sweet cocoa flavor, since the fruits contained in these mixed juices (umbu and cocoa) are known in the region.

Juices B2, D2 and D1 (Figure 2) are associated with the characteristic aroma of mango, mango flavor, brightness and sweet aroma. These juices contain mango pulp, which justifies the associations cited above. Mixed juices B3 and B4 have the same relationship with the attributes, however, less sensitive in the description of the evaluators.

Regarding beverages B1, D3 and D4, which have the highest concentrations of caja juice, there was an association between the attributes yellow color, acidic flavor of caja and characteristic aroma of caja.

For the RV coefficient, which is the correlation between the two matrices generated by the correspondence analysis of the two regions, the value found was 0.494 . Although this correlation was low, it was significant $(\mathrm{p}<0.05)$, that is, there was little consensus in the description of the samples between consumers in Porto Alegre-RS and in Salvador-BA, the two regions having a divergent acceptance of the proposed mixed juices in relation to flavor, which can explain this result. Koppel et al. (2014), in a study with functional juices, reported that, independent of the city considered, there was greater cultural diversity than divergence between consumers. The fact that Porto Alegre-RS and SalvadorBA have different eating habits cannot justify the divergence in the detailing of the mixed juices, this being due to the behavior of the consumers when faced with the flavors presented.

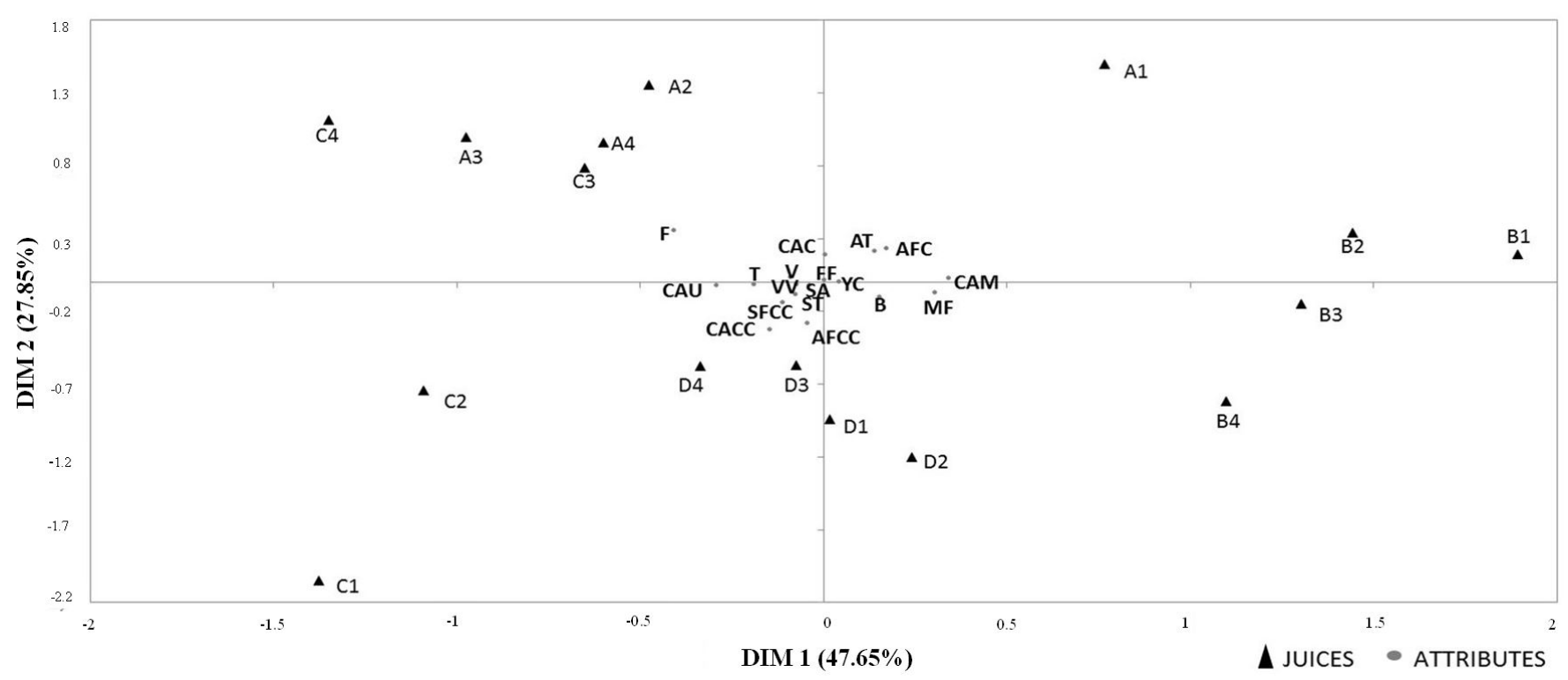

Figure 1. Correspondence analysis for Porto Alegre-RS without greenish color, associating the data from the CATA test $(\mathrm{n}=113)$ with the mixed juices. Attributes: YC (Yellow Color); GC (Greenish Color); B (Brightness); F (Foam); T (Turbidity); VV (Visual Viscosity); CAC (Characteristic Aroma of Caja); CACC (Characteristic Aroma of Cocoa); SA (Sweet Aroma); CAM (Characteristic Aroma of Mango); CAU (Characteristic Aroma of Umbu); AT (Acidic Taste); AFC (Acidic Flavor of Caja); ST (Sweet Taste); MF (Mango Flavor); SFCC (Sweet Flavor of Cocoa); FF (Fruit Flavor); AFCC (Acidic Flavor of Cocoa); and V (Viscosity). Juices: Group A (caja, umbu and cocoa); Group B (caja, umbu and mango); Group C (cocoa, mango and umbu); Group D (cocoa, mango and caja). 


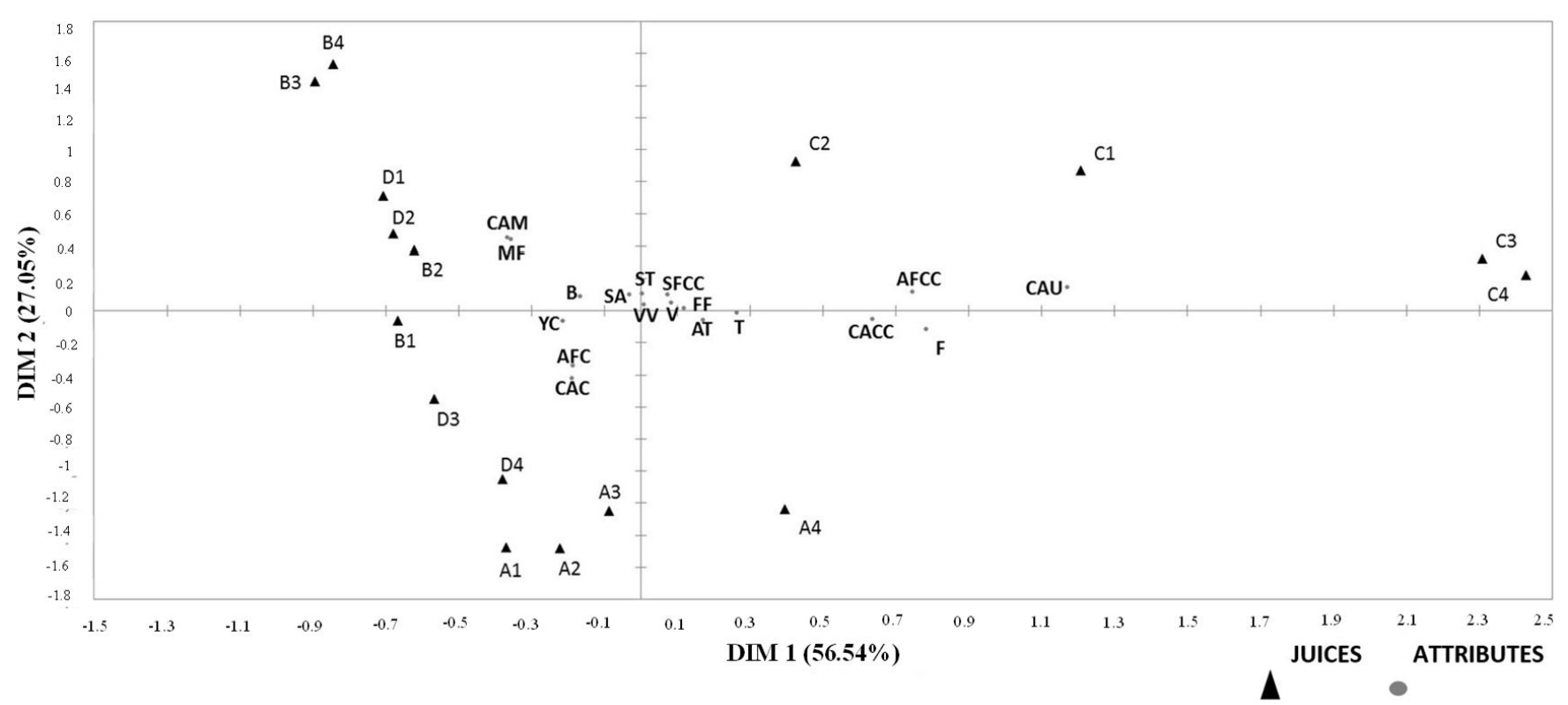

Figure 2. Correspondence analysis for Salvador-BA without greenish color, associating the data from the CATA test ( $\mathrm{n}=113)$ with the mixed juices. Attributes: YC (Yellow Color); GC (Greenish Color); B (Brightness); F (Foam); T (Turbidity); VV (Visual Viscosity); CAC (Characteristic Aroma of Caja); CACC (Characteristic Aroma of Cocoa); SA (Sweet Aroma); CAM (Characteristic Aroma of Mango); CAU (Characteristic Aroma of Umbu); AT (Acidic Taste); AFC (Acidic Flavor of Caja); ST (Sweet Taste); MF (Mango Flavor); SFCC (Sweet Flavor of Cocoa); FF (Fruit Flavor); AFCC (Acidic Flavor of Cocoa); and V (Viscosity). Juices: Group A (caja, umbu and cocoa); Group B (caja, umbu and mango); Group C (cocoa, mango and umbu); Group D (cocoa, mango and caja).

In the multiple factorial analysis, $\mathrm{A} 1$ and $\mathrm{A} 3$ juices, which had the highest acceptance scores (Table 2) in Porto Alegre-RS (Figure 3), were associated with the attributes yellow color, fruit flavor, mango flavor, characteristic mango aroma, characteristic aroma of caja and no interaction with physicochemical variables. This shows that there are similarities in their sensory profiles and explains their highest scores in that region. In Salvador-BA (Figure 4) the A1, A2 and A3 juices were associated with the descriptors and physicochemical variables: acid flavor of caja, characteristic aroma of caja, yellow color, characteristic aroma of mango, visual viscosity, viscosity and soluble solids ( ${ }^{\circ}$ Brix).

The attributes brightness, acid taste of caja and acid taste, together with the physicochemical variables viscosity, total acidity and soluble solids ( $\left.{ }^{\circ} \mathrm{Brix}\right)$, are directly integrated with all the juices of Group B, as well as with the juices A2 and A4 in the Southern region (Figure 3). In the Northeast region (Figure 4) all group $\mathrm{B}$ juices were associated with the same descriptive terms and variables of the A1, A2 and A3 juices (Figure 4).

Group C was not associated with acceptance in any of the regions, possibly because they presented the lowest grades in both cities. They showed to be associated, in the South region (Figure 3), with the terms characteristic umbu aroma and greenish color and there were no references to the physicochemical variables. In the Northeast region (Figure 4), the group C (C1, C2 and C3) juices were integrated into the descriptor and physicochemical variables: turbidity, viscosity, foam, characteristic umbu aroma, fruit flavor, characteristic cocoa aroma, acid taste of cocoa, sweet taste of cocoa, color $\mathrm{h}^{\star}$ and color $\mathrm{L}^{*}$.

It was verified that the physicochemical variables were not interacted with the acceptance in Porto Alegre-RS, and it is possible to say that these results may not have influenced the acceptance of the products by the consumers, but only the descriptor terms were determinants. In Salvador-BA the $\mathrm{pH}$, color $\mathrm{C}^{*}$ and soluble solids ( $\left.{ }^{\circ} \mathrm{Brix}\right) /$ total acidity variables were integrated with the acceptance, showing that these parameters may have influenced consumers, possibly because they were aware of the flavors used.

Samples of Group D in Porto Alegre-RS (Figure 3) are directly associated with physicochemical variables and descriptor terms: soluble solid ratio ( $\left.{ }^{\circ} \mathrm{Brix}\right) /$ total acidity, $\mathrm{pH}$, color $\mathrm{C}^{*}$, $\mathrm{L}^{*}$ and $\mathrm{h}^{*}$ sweet taste, sweet aroma, sweet cocoa flavor, viscosity, visual viscosity, characteristic cocoa flavor, acid cocoa taste, foam and turbidity. In Salvador-BA (Figure 4), the physicochemical attributes and variables associated to this juice group were: mango flavor, brightness, sweet aroma, sweet taste, $\mathrm{pH}$, color $\mathrm{C}^{*}$, soluble solids ratio ( $\left.{ }^{\circ} \mathrm{Brix}\right) /$ acidity total.

These beverages in Porto Alegre-RS were linked to the greatest number of attributes and variables, but were not associated with acceptance, in contrast, in Salvador-BA because they were directly associated with acceptance, they showed that their descriptive sensorial profiles are similar because they had in their composition the cocoa, mango and caja flavors, in different concentrations and had the highest scores.

In the South of the country, the seasonal production of typically temperate climate fruits predominates, such as apple, grape, peach, strawberry, blackberry and blueberry. The northeast of Brazil produces large amounts of fruits such as melon, mango, grape and cocoa, and a typically family agricultural production of exotic fruits such as caja and umbu. Caja and umbu are typical fruits of semi-arid regions and are only produced and consumed in the northeast of Brazil (Beling, 2008). The data produced in this 

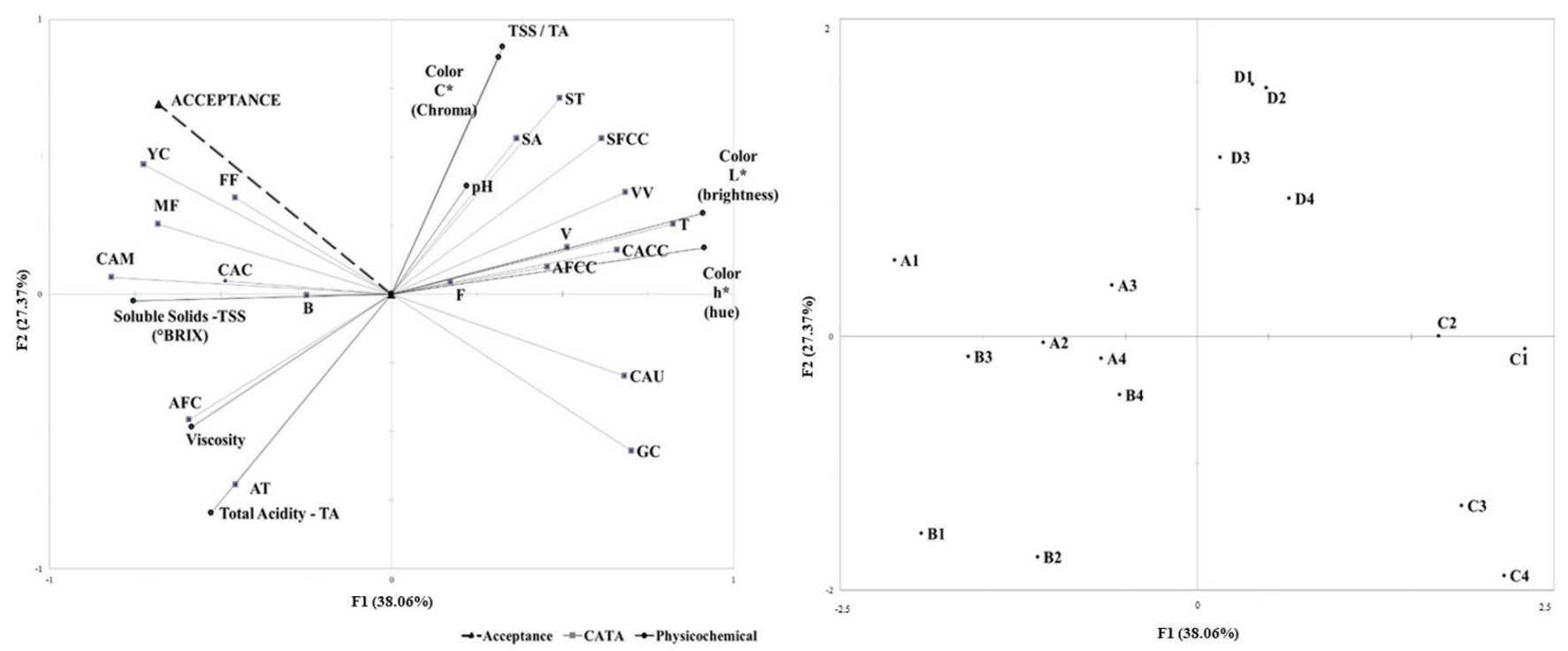

Figure 3. Multiple factorial analysis associating the CATA test data for the mixed juices, the acceptance test $(\mathrm{n}=113)$ and the physicochemical variables obtained in Porto Alegre-RS of mixed juices. Attributes: YC (Yellow Color); GC (Greenish Color); B (Brightness); F (Foam); T (Turbidity); VV (Visual Viscosity); CAC (Characteristic Aroma of Caja); CACC (Characteristic Aroma of Cocoa); SA (Sweet Aroma); CAM (Characteristic Aroma of Mango); CAU (Characteristic Aroma of Umbu); AT (Acidic Taste); AFC (Acidic Flavor of Caja); ST (Sweet Taste); MF (Mango Flavor); SFCC (Sweet Flavor of Cocoa); FF (Fruit Flavor); AFCC (Acidic Flavor of Cocoa); and V (Viscosity). Physicochemical variables: Total Acidity-TA; Soluble Solids-TSS ( ${ }^{\circ}$ Brix); Color C* (Chroma); TSS/TA; Color L* (Brightness); Color h* (hue); Viscosity. Juices: Group A (caja, umbu and cocoa); Group B (caja, umbu and mango); Group C (cocoa, mango and umbu); Group D (cocoa, mango and caja).
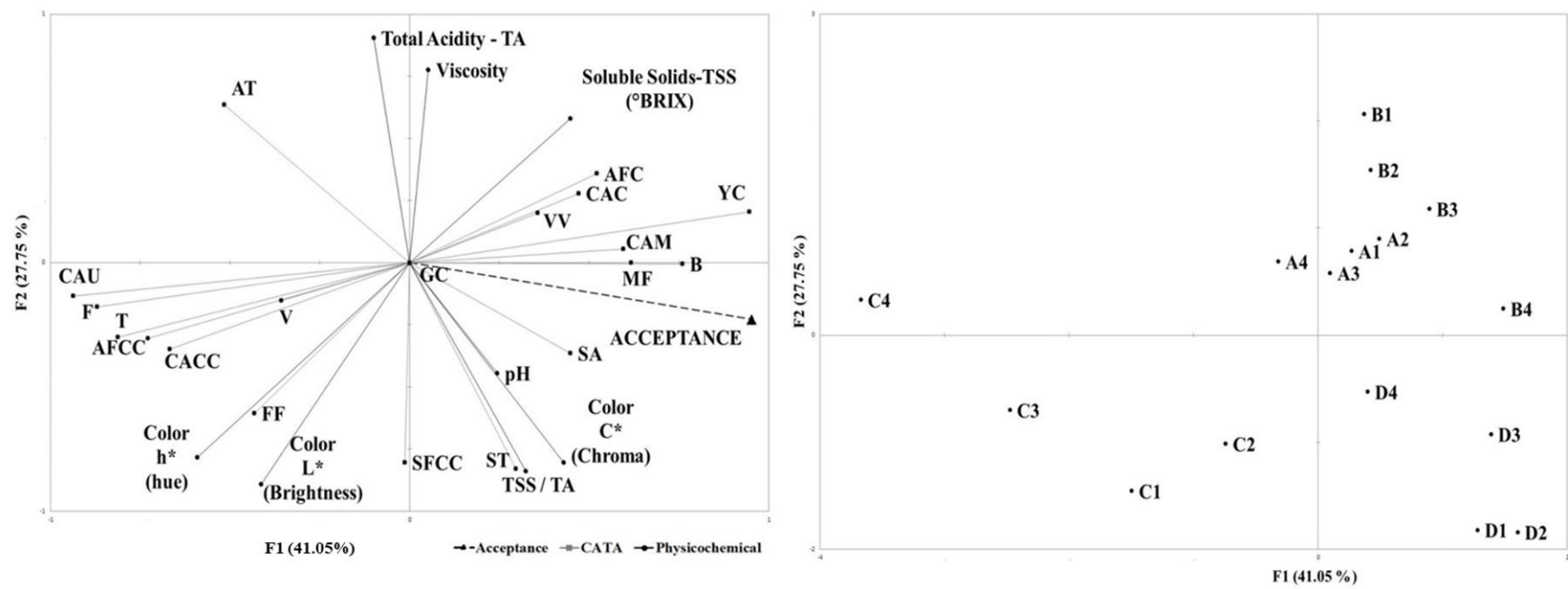

Figure 4. Multiple factor analysis associating the CATA test data for the mixed juices, the acceptance test $(\mathrm{n}=113)$ and the physicochemical variables obtained in Salvador-BA. Attributes: YC (Yellow Color); GC (Greenish Color); B (Brightness); F (Foam); T (Turbidity); VV (Visual Viscosity); CAC (Characteristic Aroma of Caja); CACC (Characteristic Aroma of Cocoa); SA (Sweet Aroma); CAM (Characteristic Aroma of Mango); CAU (Characteristic Aroma of Umbu); AT (Acidic Taste); AFC (Acidic Flavor of Caja); ST (Sweet Taste); MF (Mango Flavor); SFCC (Sweet Flavor of Cocoa); FF (Fruit Flavor); AFCC (Acidic Flavor of Cocoa); and V (Viscosity). Physicochemical variables: Total Acidity-TA; Soluble Solids-TSS ( ${ }^{\circ}$ Brix); Color C* (Chroma); TSS/TA; Color L* (Brightness); Color h (hue); Viscosity. Juices: Group A (caja, umbu and cocoa); Group B (caja, umbu and mango); Group C (cocoa, mango and umbu); Group D (cocoa, mango and caja).

study show that even though they are unknown in the southern region, caja and umbu show the potential for consumption in other parts of the country. The results are important to the producers of these fruits, with a view to the development and improvement in the economic situation of small farmers in the northeastern region. However, it is worth mentioning that it is necessary to carry out additional tests with projective and innovative methods based on the perception of consumers. Such methods can consistently contribute to the interpretation of results and may be applied routinely in the development of marketing strategies and approaches (Pacheco et al., 2018; Judacewski et al., 2019; Soares et al., 2019; Speight et al., 2019; Rodrigues et al., 2020). 


\section{Conclusions}

The use of CATA questions could be an interesting, simple and rapid methodology to evaluate the consumer perception, with a complete description of the product. One must also consider that the alliance between CATA, the hedonic scale and the correspondence analysis make it possible to understand the acceptance and the sensory attributes. The answers gathered by the multiple factorial analysis of the two regions concurred with the discrepancy in acceptance amongst the samples, suggesting the validity of the consumer data in the characterization of the sensory parameters of the mixed juices evaluated. It should be noted that the evaluation of the juices could identify groups of consumers in each city with different standards of acceptance, since there was a mixed juice capable of meeting the sensory and hedonic expectations of all the consumers. An interesting conclusion of the present study was that unfamiliarity with some tropical fruit flavors seems to markedly affect the quality perceived, when comparing one region with another, suggesting that the selection of flavors for mixed juices may be critical in the development of these beverages. Although the methodologies applied seem to have validity in characterizing the sensory properties of the juices as they are perceived, further studies could investigate the influence of the order and number of terms considered in the CATA questions, as well as comparing the results obtained from a trained panel using descriptive quantitative analysis.

\section{Acknowledgements}

To the judges who took part in the Sensory Analysis; to the Faculty of Medicine of the Federal University of Rio Grande do Sul (UFRGS), especially to professors Viviani Ruffo and Vanuska da Silva and to the Coordination for the Improvement of Higher Education Personnel (CAPES).

\section{References}

Alencar, N. M. M., Ribeiro, T. G., Barone, B., Barros, A. P. A., Marques, A. T. B., \& Behrens, J. H. (2019). Sensory profile and check-all-thatapply (cata) as tools for evaluating and characterizing syrah wines aged with oak chips. Food Research International, 124, 156-164. http://dx.doi.org/10.1016/j.foodres.2018.07.052. PMid:31466634.

Ares, G., Barreiro, C., Deliza, R., Giménez, A., \& Gámbaro, A. (2010a). Application of a check-all-that-apply questions to the development of chocolate milk desserts. Journal of Sensory Studies, 25, 67-86. http://dx.doi.org/10.1111/j.1745-459X.2010.00290.x.

Ares, G., Deliza, R., Barreiro, C., Giménez, A., \& Gámbaro, A. (2010b). Comparison of two sensory profiling techniques based on consumer perception. Food Quality and Preference, 21(4), 417-426. http:// dx.doi.org/10.1016/j.foodqual.2009.10.006.

Ares, G., Jaeger, S. R., Bava, C. M., Chheang, S. L., Jin, D., Giménez, A., Vidal, L., Fiszman, S. M., \& Varela, P. (2013). CATA questions for sensory product characterization-raising awareness of biases. Food Quality and Preference, 30(2), 114-127. http://dx.doi.org/10.1016/j. foodqual.2013.04.012.

Association of Official Analytical Chemist - AOAC. (1995). Official methods of analysis of AOAC international (16 ${ }^{\text {th }} \mathrm{ed}$.). Rockville: AOAC.

Beling, R. R. (Ed.). (2008). Anuário Brasileiro de Fruticultura 2008 (136 p.). Santa Cruz do Sul: Editora Gazeta.
Bonany, J., Buehler, A., Carbó, J., Codarin, S., Donati, F., Echeverria, G., Egger, S., Guerra, W., Hilaire, C., Höller, I., Iglesias, I., Jesionkowska, K., Konopacka, D., Kruczyńska, D., Martinelli, A., Pitiot, C., Sansavini, S., Stehr, R., \& Schoorl, F. (2013). Consumer eating quality acceptance of new apple varieties in different European countries. Food Quality and Preference, 30(2), 250-259. http://dx.doi. org/10.1016/j.foodqual.2013.06.004.

Bonneau, A., Boulanger, R., Lebrun, M., Maraval, I., \& Gunata, Z. (2016). Aroma compounds in fresh and dried mango fruit (Mangifera indica L. cv. Kent): impact of drying on volatile composition. International Journal of Food Science \& Technology, 51(3), 789-800. http://dx.doi. org/10.1111/ijfs.13038.

Brasil. Ministério da Agricultura, Pecuária e Abastecimento. (2003). Instrução normativa $\mathrm{n}^{\circ} .12$, de 4 de setembro de 2003 . Regulamento técnico geral para fixação de identificação e qualidade gerais para suco tropical. Diário Oficial [da] República Federativa do Brasil. Retrieved from http://www.idec.org.br/pdf/instrucao-normativa-12.pdf

Cruz, A. G., Cadena, R. S., Castro, W. F., Esmerino, E. A., Rodrigues, J. B., Gaze, L., Faria, J. A. F., Freitas, M. Q., Deliza, R., \& Bolini, H. M. A. (2013). Consumer perception of probiotic yogurt: Performance of check all hat apply (CATA), projective mapping, sorting and intensity scale. Food Research International, 54(1), 601-610. http:// dx.doi.org/10.1016/j.foodres.2013.07.056.

Duarte, W. F., Dias, D. R., Oliveira, J. M., Teixeira, J. A., de Almeida e Silva, J. B., \& Schwan, R. F. (2010). Characterization of different fruit wines made from cacao, cupuassu, gabiroba, jaboticaba and umbu. Lebensmittel-Wissenschaft + Technologie, 43(10), 1564-1572. http://dx.doi.org/10.1016/j.lwt.2010.03.010.

Efraim, P., Pezoa-García, N. H., Jardim, D. C. P., Nishikawa, A., Haddad, R., \& Eberlin, M. N. (2010). Influência da fermentação e secagem de amêndoas de cocoa no teor de compostos fenólicos e na aceitação sensorial. Food Science and Technology (Campinas), 30, 142-150. http://dx.doi.org/10.1590/S0101-20612010000500022.

Farah, J. S., Araujo, C. B., \& Melo, L. (2017). Analysis of yoghurts', whey-based beverages' and fermented milks' labels and differences on their sensory profiles and acceptance. International Dairy Journal, 68, 17-22. http://dx.doi.org/10.1016/j.idairyj.2016.12.008.

Gilbert, A. N., \& DiVerdi, J. A. (2019). Use of rating scales versus checkall-that-apply ballots in quantifying strain-specific Cannabis aroma. Journal of Sensory Studies, 34, e12499. http://dx.doi.org/10.1111/ joss. 12499.

Hough, G., Wakeling, I., Mucci, A., Chambers, I. V. E. 4th, Gallardo, I. M., \& Alves, L. R. (2006). Numbers of consumers necessary for sensory acceptability tests. Food Quality and Preference, 17(6), 522526. http://dx.doi.org/10.1016/j.foodqual.2005.07.002.

Jaekel, L. Z., Rodrigues, R. S., \& Silva, A. P. (2010). Avaliação físicoquímica e sensorial de bebidas com diferentes proporções de extratos de soja e de arroz. Food Science and Technology (Campinas), 30(2), 342-348. http://dx.doi.org/10.1590/S0101-20612010000200009.

Judacewski, P., Los, P. R., Lima, L. S., Alberti, A., Zielinski, A. A. F., \& Nogueira, A. (2019). Perceptions of Brazilian consumers regarding White mould surface-ripened cheese using free word association. International Journal of Dairy Technology, 72(4), 585-590. https:// doi.org/10.1111/1471-0307.12649.

Kemp, B., Trussler, S., Willwerth, J., \& Inglis, D. (2019). Applying temporal check-all-that-apply (TCATA) to mouthfeel and texture properties of red wines. Journal of Sensory Studies, 34, e12503. http:// dx.doi.org/10.1111/joss.12503.

Kim, M. K., \& Kwak, H. S. (2015). Influence of functional information on consumer liking and consumer perception related to health claims for blueberry functional beverages. International Journal of 
Food Science \& Technology, 50(1), 70-76. http://dx.doi.org/10.1111/ ijfs. 12627.

Koppel, K., Chambers, I. V. E. 4th, Vázquez-Araújo, L., Timberg, L., Carbonell-Barrachina, A. A., \& Suwonsichon, S. (2014). Crosscountry comparison of pomegranate juice acceptance in Estonia, Spain, Thailand, and United States. Food Quality and Preference, 31, 116-123. http://dx.doi.org/10.1016/j.foodqual.2013.03.009.

Lima, A. S., Maia, G. A., Sousa, P. H. M., Prado, G. M., \& Rodrigues, S. (2009). Storage stability of a stimulant coconut water-acerola fruit juice beverage. International Journal of Food Science \& Technology, 44, 1445-1451. http://dx.doi.org/10.1111/j.1365-2621.2009.01977.x.

MacFie, H. J. J., Bratchell, N., Greenhoff, K., \& Vallis, L. V. (1989). Designs to balance the effect of order of presentation and first-order carry-over effects in hall tests. Journal of Sensory Studies, 4(2), 129148. http://dx.doi.org/10.1111/j.1745-459X.1989.tb00463.x.

Mamede, M. E. O., Kalschne, D. L., Santos, A. P. C., \& Benassi, M. T. (2015). Caja-flavored drinks: a proposal for mixed flavor beverages and a study of the consumer profile. Food Sci Technol., 35(1), 143149. http://dx.doi.org/10.1590/1678-457X.6563.

Meilgaard, G. K., \& Civille, G. V. (2007). Carr BI Sensory evalution techniques: marketing and R \& D approaches. (4th ed.). Boca Raton, FL: CRC Pressa.

Meyners, M., Castura, J. C., \& Carr, B. T. (2013). Existing and new approaches for the analysis of CATA data. Food Quality and Preference, 30(2), 309-319. http://dx.doi.org/10.1016/j.foodqual.2013.06.010.

Moskowitz, H. R. (1983). Product testing and sensory evaluation of foods: marketing and $R$ \& $D$ approaches. Westport, CT: Food and Nutrition Press.

Neves, M. V. M., \& Lima, V. L. A. G. (2010). Avaliação sensorial e caracterização físico-química de néctar de acerola adicionado de extrato comercial de própolis. Brazilian Journal of Food and Nutrition, 21(3), 399-405. Retrieved from http://serv-bib.fcfar.unesp.br/seer/ index.php/alimentos/article/viewFile/1098/1098

Pacheco, M. H. S., Kuriya, S. P., Capobiango, C. S. C., Pimentel, T. C., Cruz, A. G., Esmerino, E. A., \& Freitas, M. Q. (2018). Exploration of gender differences in bottled mineral water consumption: a projective study of consumer's perception in Brazil. Journal of Sensory Studies, 33(4), e12434. http://dx.doi.org/10.1111/joss.12434.

Pramudya, R. C., \& Seo, H. S. (2018). Using Check-All-That-Apply (CATA) method for determining product temperature-dependent sensory-attribute variations: a case study of cooked rice. Food Research International, 105, 724-732. http://dx.doi.org/10.1016/j. foodres.2017.11.075. PMid:29433267.

Rodrigues, J. F., Mangia, B. A., Silva, J. G., Lacorte, G. A., Coimbra, L. O., Esmerino, E. A., Freitas, M. Q., Pinheiro, A. C. M., \& Cruz, A.
G. (2020). Sorting task as a tool to elucidate the sensory patterns of artisanal cheeses. Journal of Sensory Studies, 35(3), e12562. https:// doi.org/10.1111/joss.12562.

Silva, L. M. R., Lima, A. S., Maia, G. A., Figueiredo, R. W., Sousa, P. H. M., \& Lima, J. S. S. (2011a). Desenvolvimento de néctares mistos à base de mango e caja enriquecidos com frutooligossacarídeos ou inulina. Brazilian Journal of Food and Nutrition, 22(1), 149-154. Retrieved from http://serv-bib.fcfar.unesp.br/seer/index.php/ alimentos/article/view/1482/1482

Silva, L. M. R., Lima, A. S., Maia, G. A., Rodrigues, M. C. P., Figueiredo, R. W., \& Sousa, P. H. M. (2011b). Desenvolvimento de bebidas mistas à base de caja (Spondias mombin L.) e caju (Anacardium occidentale) enriquecidos de frutooligossacarídeos e inulina. ALAN Archivos LatinoAmericanos de Nutrición, 61(2), 209-215. Retrieved from http://www.alanrevista.org/ediciones/2011/2/art-13/

Soares, E. K. B., Silva, R., Silva, W. P., Kuriya, S. P., Maçaira, P. M., Oliveira, F. L. C., Silva, M. A. A. P., Pimentel, T. C., Freitas, M. Q., Cruz, A. G., \& Esmerino, E. A. (2019). An intra-cultural investigation in Brazil using Coalho cheese and preferred attribute elicitation. Journal of Sensory Studies, 35(1), e12543. https://doi.org/10.1111/joss.12543.

Sousa, P. H. M., Ramos, A. M., Maia, G. A., Brito, E. S., Garruti, D. S., \& Fonseca, A. V. V. (2010). Adição de extratos de Ginkgo biloba e Panax ginseng em néctares mistos de frutas tropicais. Food Science and Technology, 30(2), 463-470. http://dx.doi.org/10.1590/S010120612010000200025.

Speight, K. C., Schiano, A. N., Harwood, W. S., \& Drake, M. A. (2019). Consumer insights on prepackaged Cheddar cheese shreds using focus groups, conjoint analysis, and qualitative multivariate analysis. Journal of Dairy Science, 102(8), 6971-6986. http://dx.doi.org/10.3168/ jds.2018-16209. PMid:31155259.

Teixeira, L. V. (2009). Análise sensorial na indústria de alimentos. Revista Instituto Laticínio Cândido Tostes, 64, 12-21.

Tiburski, J. H., Rosenthal, A., Deliza, R., Godoy, R. L. O., \& Pacheco, S. (2011). Nutritional properties of yellow mombin (Spondias mombin L.) pulp. Food Research International, 44(7), 2326-2331. http://dx.doi. org/10.1016/j.foodres.2011.03.037.

Torres, F. R., Esmerino, E. A., Carr, B. T., Ferrão, L. L., Granato, D., Pimentel, T. C., Bolini, H. M. A., Freitas, M. Q., \& Cruz, A. G. (2017). Rapid consumer-based sensory characterization of requeijão cremoso, a spreadable processed cheese: performance of new statistical approaches to evaluate check-all-that-apply data. Journal of Dairy Science, 100(8), 6100-6110. http://dx.doi.org/10.3168/ jds.2016-12516. PMid:28571992.

Verwaeren, J., Gellynck, X., Lagast, S., \& Schouteten, J. J. (2019). Predicting children's food choice using check-all-that-apply questions. Journal of Sensory Studies, 34(1), e12471. http://dx.doi.org/10.1111/joss.12471. 